\title{
The influence of body temperature and castration on the protein composition of fluid in the rat cauda epididymidis*
}

\author{
P. Esponda† and J. M. Bedford \\ Departments of Obstetrics and Gynecology and of Cell Biology and Anatomy, \\ Cornell University Medical College, New York, NY 10021, U.S.A.
}

\begin{abstract}
Summary. Polyacrylamide gel electrophoresis under reducing and non-reducing conditions, and immunoelectrophoretic analysis, revealed that several characteristic proteins disappear from the luminal fluid of the rat cauda epididymidis when it is maintained at body temperature. On SDS-PAGE gels prepared under reducing conditions, one Coomassie-blue staining band of $M_{\mathrm{r}} 18000$ disappeared and another of 52000 was significantly reduced after only 6 days; bands of $M_{\mathrm{r}} 23000$, several in the $M_{\mathrm{r}}$ 34-38000 range, one of $M_{\mathrm{r}} 48000$, and others of $M_{\mathrm{r}} 100-200000$ were eliminated or markedly reduced after 15 days at body temperature. Some were glycoprotein, as judged by their affinity for FITC-ConA. At 15 days after castration there was a broadly similar but rather more extensive disappearance of macromolecules, and of glycoproteins in particular, from caudal fluid. The fact that several similar proteins are diminished in or disappear from fluid or the cauda epididymidis maintained at body temperature, or after androgen withdrawal, raises the possibility that one or more such proteins play a role in sperm storage there.
\end{abstract}

\section{Introduction}

The terminal region of the epididymis, the cauda, serves as a storage site for spermatozoa after completing their maturation and, in scrotal mammals at least, this houses more spermatozoa than any other region (see Amann, 1981). Storage appears to depend on special conditions created in the cauda epididymidis. Spermatozoa cannot survive for more than a few days in the upper epididymal regions involved in maturation, whereas some can remain fertile for a period of up to several weeks in the environment of the cauda (Hammond \& Asdell, 1926). Little is known about the identity of the factors that are the key to the specialized storage properties of the caudal luminal fluid. However, in view of mounting evidence that secretory epididymal proteins play a role in sperm maturation (Orgebin-Crist \& Jahad, 1978; Lea, Petrusz \& French, 1978), the possibility exists that other specific proteins facilitate sperm survival in the cauda.

In considering ways to approach such a question we have taken account of the fact that the ability of the cauda to maintain spermatozoa in a viable state is rapidly eliminated when androgenic support of the epithelium is withdrawn (Moore, 1928; Dyson \& Orgebin-Crist, 1973; Orgebin-Crist, Danzo \& Davies, 1975) or, in scrotal mammals, when the cauda is raised to body temperature (Heller, 1929; Glover, 1960; Foldesy \& Bedford, 1982). We have studied the effect of body temperature on the profile of proteins in the lumen of the cauda epididymidis, and compared this with the effects caused by androgen deprivation due to castration.

\footnotetext{
*Reprint requests to J. M. Bedford.

†Present address: Centro de Investigaciones Biologicas, C.S.I.C. Velazquez 144, Madrid, 28006, Spain.
} 


\section{Materials and Methods}

Epididymal fluid collection. Epididymal fluid samples were obtained from 37 adult Sprague-Dawley rats $(400-500 \mathrm{~g})$. Before fluid collection, some experimental animals were castrated leaving the epididymis in the scrotum. In others, one epididymis was reflected to the abdomen, leaving the testis in the scrotum (Bedford, 1978; Foldesy \& Bedford, 1982). In the latter, sham operations were performed on the control side and in all groups special care was taken to avoid bleeding into the vaginal process.

Since spermatozoa still develop the ability to fertilize in the epididymis reflected to the abdomen (Bedford, 1978), body temperature may have little or no effect on the functions of the epithelium in the upper regions of the epididymis, in contrast to demonstrated effects on the epithelium of the cauda (Wong, Au \& Bedford, 1982; Rasweiler \& Bedford, 1982). This consideration seemed especially relevant to the present project because some proteins of very similar electrophoretic mobility appear in SDS-PAGE gels of caput and cauda fluids (Turner, Plesums \& Cabot, 1979). Pilot analyses of the caudal content from 2 rats revealed that division of the epididymal duct in the distal corpus region 15 days previously did not itself change the caudal SDS-PAGE spectrum from that seen in the normal duct. Therefore, to forestall any possible contribution to the caudal fluid from the upper regions after castration or epididymal reflection to the abdomen, in Groups A, B and $\mathrm{C}$ described below the duct was neatly incised in the distal corpus region on the control and experimental sides, without disturbing the epididymal vascular supply, the cut ends being ligated with 6-0 silk.

The experimental groups (explained in Fig. 1) were as follows. Group A: one epididymis ligated in the distal corpus region was reflected to the abdomen for 15 days, the contralateral epididymis remaining in the scrotum (Fig. 1a: 12 rats). Group B: a similar procedure as for Group A, but fluids were collected after only 6 days (Fig. 1a: 4 rats). Group C: bilateral castration, leaving the epididymis in the scrotum for 15 days (Fig. 1 b: 7 rats). Group D: using microsurgical techniques, an obstructing ligature of (6-0) braided silk was placed bilaterally around a single tubule in the flexure of the cauda epididymidis on both sides, at the point shown in Fig. 1(c). After this, one epididymis was replaced in the scrotum and the other was retained in the abdomen ( 3 rats for 6 days; 3 rats for 13 days).

For fluid collection, animals were killed with chloroform, the epididymides were removed and the caudal content collected by retrograde perfusion from the large tubules of the caudal flexure. This was achieved by inserting a 21-gauge needle connected to a Buchler peristaltic pump into the upper segment of the vas deferens, such that the tip began to enter the corrugated tubule of the distal cauda. Coloured castor oil was pumped in and the content of the large tubules was collected, without contamination, from an incision at the arrow in Fig. 1(c). The content was then centrifuged for $10 \mathrm{~min}$ at $8700 \mathrm{~g}$ in a microfuge to separate spermatozoa from the viscous caudal fluid.

Protein analyses. After determination of its protein concentration (Lowry, Rosebrough, Farr \& Randall, 1951) the caudal fluid was subjected to electrophoresis on sodium dodecyl sulphate polyacrylamide (SDS-PAGE) gels. This was performed as described by Laemmli (1970) with minor modifications, using reducing conditions and non-reducing conditions. In the latter, mercaptoethanol was omitted from the sample buffer. In the stacking and separation gels, $2 \cdot 5 \%$ and $10 \%$ acrylamide concentrations were used, respectively. Samples for analysis in reducing conditions were boiled for $2 \mathrm{~min}$ in $30 \mathrm{~mm}$-Tris- $\mathrm{HCl}$ (pH 6.8) buffer containing $1 \%$ SDS, $10 \%$ glycerol, $0.002 \%$ bromphenol blue and $5.2 \%$ mercaptoethanol. After loading with known amounts of protein together with molecular weight standards (Bio-Rad, South Richmond, CA) in parallel, the gels were run at $25 \mathrm{~mA}$ at a constant current. On completion, they were fixed in a water/ethanol/ acetic acid mixture (6:4:1 by vol.), stained with $0 \cdot 1 \%$ Coomassie Brilliant Blue (R-250), then destained in the fixative solution. Additional gels were stained with FITC-Concanavalin A (FITCConA) to identify glycoproteins. To do this, fixed gels were thoroughly washed with phosphate buffer (pH 7.2) and incubated with $0.5 \mathrm{mg}$ FITC-ConA $/ \mathrm{ml}$ (Cappel Laboratories, West Chester, 


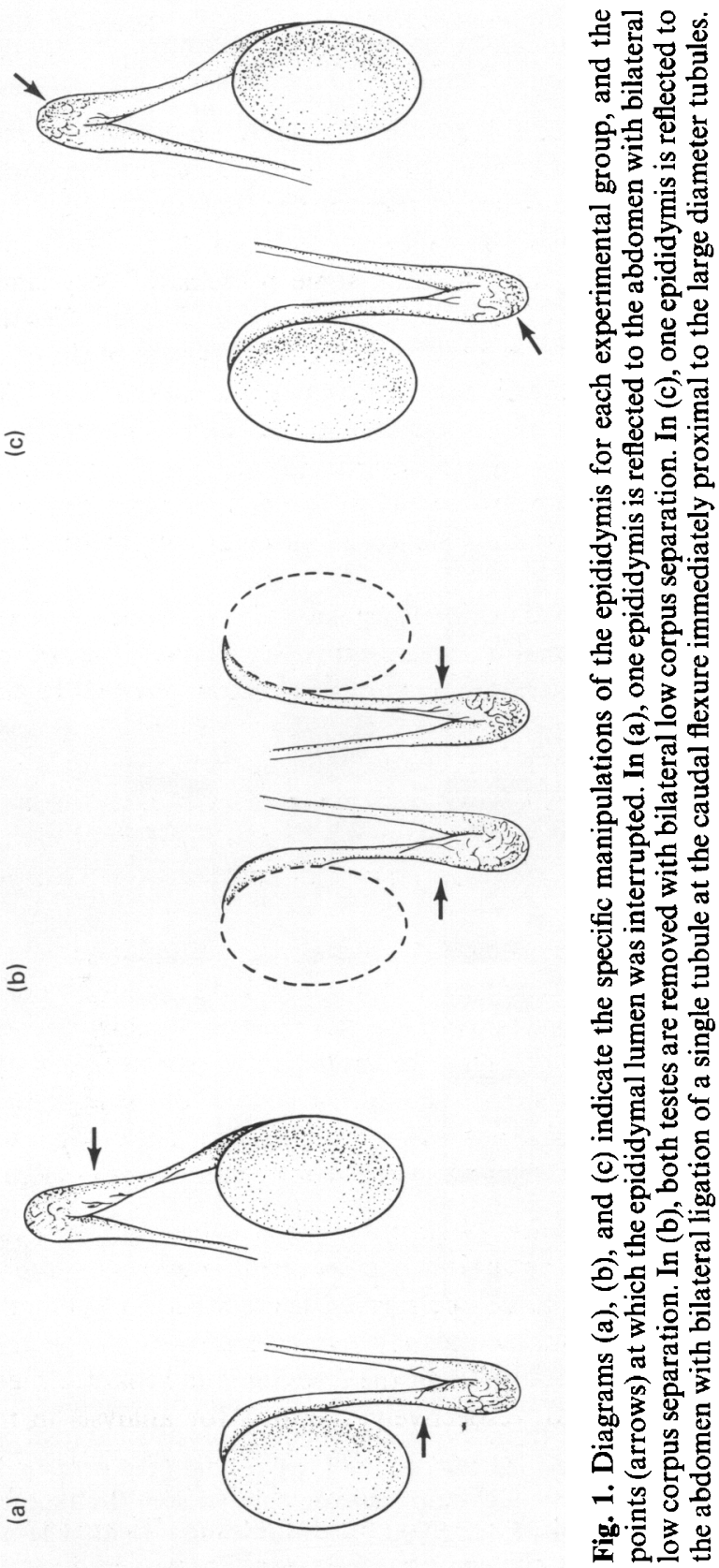


PA), and after washing were studied and photographed under ultraviolet light. To obtain a better resolution of higher molecular weight proteins, other samples prepared under reducing conditions were run with $3.5 \%$ and $4 \%$ acrylamide concentrations in the stacking and separation gels, respectively. These gels were later stained by means of the silver method of Wray, Boulikas, Wray \& Hancock (1981).

Normal and 15-day cryptic caudal fluids were also analysed by immunoelectrophoresis. Antibody against the fluid from a control cauda epididymidis was first raised in rabbits by intradermal injection of $\sim 200 \mu \mathrm{g}$ cauda fluid protein plus Freund's Complete Adjuvant. This was followed at weekly intervals by 4 repeat injections together with Freund's Incomplete Adjuvant. Then the rabbit serum was tested for antibody using Ouchterlony immunodiffusion plates. Immunoelectrophoresis was performed using 1\% agarose gels (made with barbital buffer, pH 8.6). Samples from normal caudal fluid and that from the 15-day cryptic cauda were run in parallel at $10 \mathrm{~mA}$. Antibody was then placed in the central trough and left for $48 \mathrm{~h}$. After development of precipitation bands, the gel was fixed and stained with Coomassie Blue.

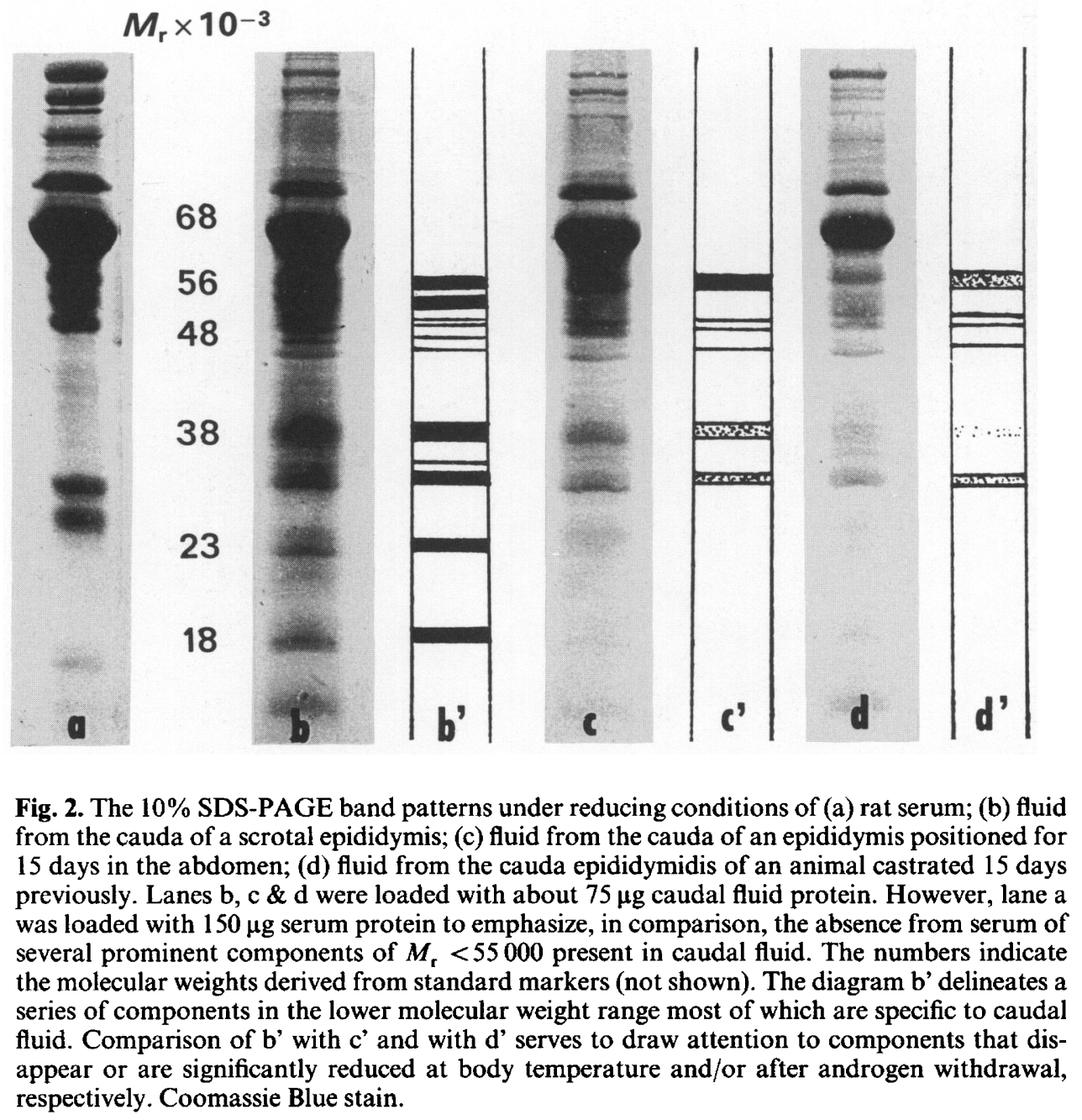




\section{Results}

Stained with Coomassie Blue, one dimensional polyacrylamide-SDS gels of normal rat caudal fluid revealed many different protein bands, most of which fell in the $M_{\mathrm{r}}$ range of 12 000-150000 (Fig. $2 b)$. Samples prepared in reducing and non-reducing conditions presented a relatively similar band pattern. However, as shown already by others (Jones, Brown, Von Glos \& Parker, 1980; Brooks \& Higgins, 1980; Brooks, 1983), a number of caudal fluid proteins differ from serum proteins. Even when twice the total protein was loaded on the serum lane, several distinct lower molecular weight bands, e.g. of $M_{\mathrm{r}} 18000,23000,34-38000$ and of about 48000 , present in cauda fluid were clearly absent from serum (see lanes a $\&$ b in Fig. 2).

Fluid taken from the scrotal cauda separated 15 days previously from the corpus region at the point shown in Fig. 1(a) (or 13 days after single tubule ligation at the lower point shown in Fig. 1c) displayed a similar electrophoretic pattern (Fig. 2b) to that of cauda fluid from the normal intact epididymis (not shown). The band changes seen at body temperature or after androgen withdrawal

$$
M_{\mathrm{r}} \times 10^{-3}
$$

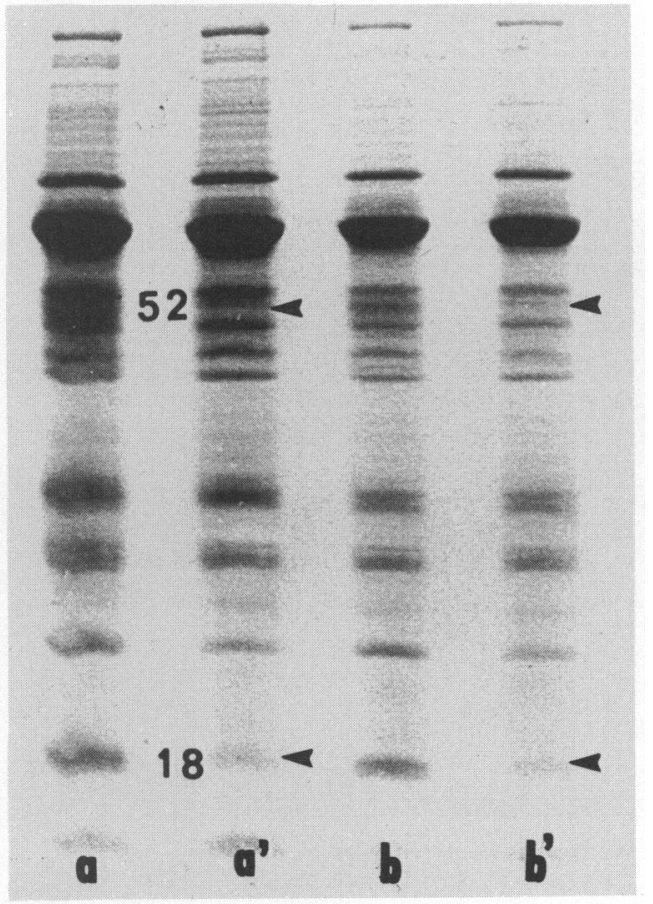

Fig. 3

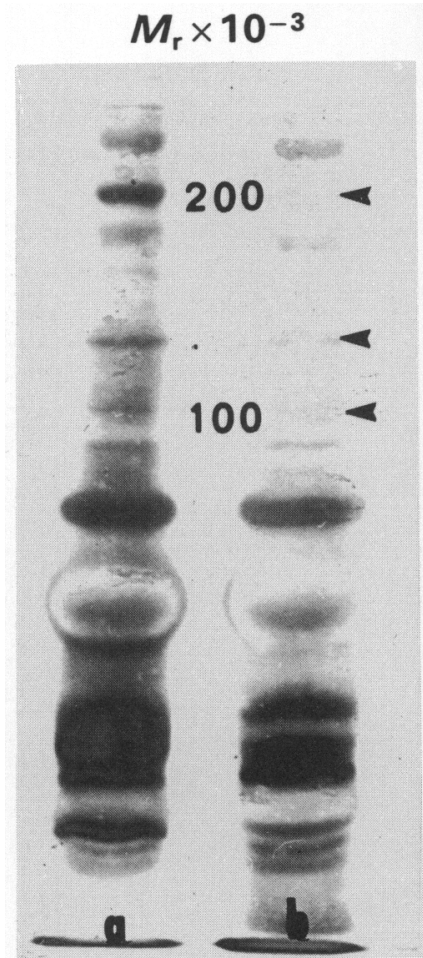

Fig. 4

Fig. 3. The 10\% SDS-PAGE gels in non-reducing conditions of fluid protein from one scrotal cauda epididymidis of each of 2 different males $(a$ and $b$ ) and that in fluid from the contralateral cauda reflected for the previous 6 days to the abdomen (a', b'). Arrows indicate a decrease in a band of $M_{\mathrm{r}} 18000$ and to a lesser degree, one of $M_{\mathrm{r}} 52000$ in response to abdominal temperature. Coomassie Blue stain.

Fig. 4. The 4\% SDS-PAGE gels under reducing conditions in which the higher molecular weight components of epididymal fluid are separated more clearly: (a) caudal fluid from a rat epididymis in the scrotal position; (b) caudal fluid from an epididymis reflected 15 days previously to the abdomen. In (b) several bands (arrowed between $M_{\mathrm{r}} 100-200000$ ) are absent or are much fainter. Silver stain. 
must therefore have reflected effects on the caudal environment per se. Such change in the protein spectrum in fluid collected from the cryptepididymal cauda began within 6 days of exposure to abdominal temperature, signalled by a disappearance of or marked reduction in bands of $M_{\mathrm{r}} 18000$ and to some degree of $M_{\mathrm{r}} 52000$ (Fig. 3). Compared with scrotal cauda fluid further loss after 15 days was manifested on $10 \%$ PAGE gels in a reduction or disappearance of a protein of $M_{\mathrm{r}} 23000$, several in the $M_{\mathrm{r}}$ 34-38000 range, and one of 48000 (Fig. 2c). By running such samples also on $3.5-4 \%$ acrylamide gels and staining by the silver method, a clear separation was obtained of epididymal proteins in the higher molecular weight range (Fig. 4). In such conditions at least 3 protein bands of $M_{\mathrm{r}} 100000-200000$, present in scrotal cauda fluid, were absent or markedly reduced in 15-day cryptepididymal fluid.

As noted above, the band pattern in control (scrotal) samples obtained 15 days after low corpus

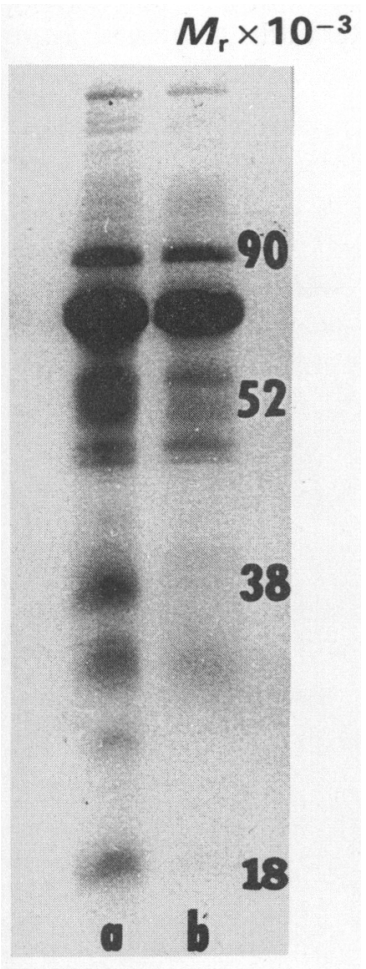

Fig. 5

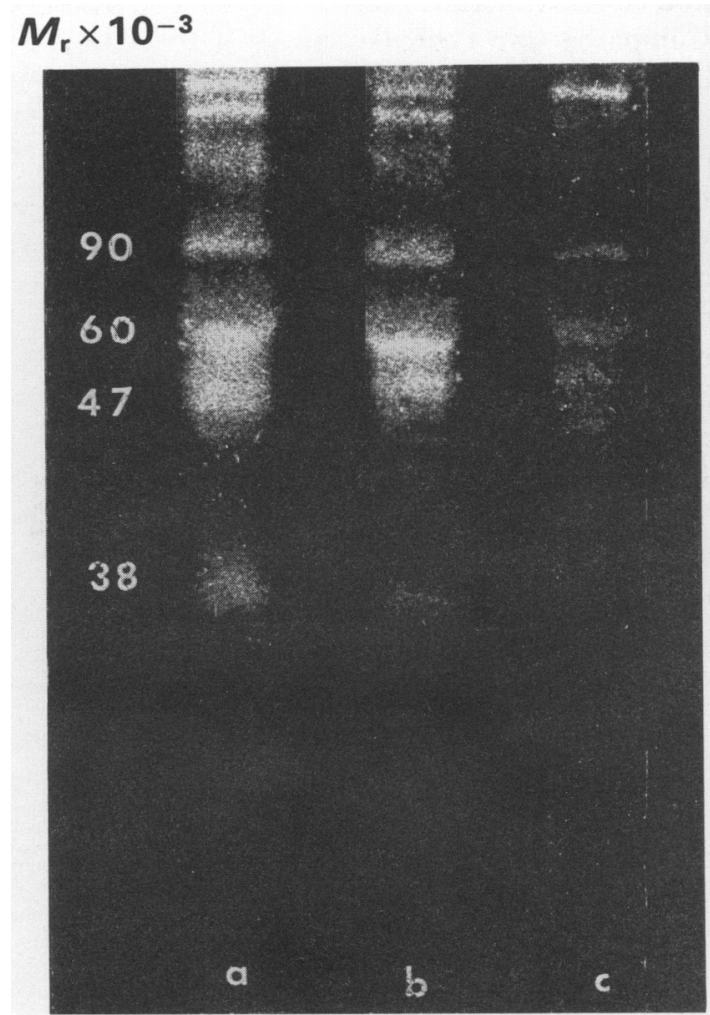

Fig. 6

Fig. 5. Typical 10\% SDS-PAGE gel run under reducing conditions of fluid protein from a rat cauda epididymidis ligated 13 days previously as shown in Fig. 1(c): (a) fluid from a scrotal epididymis; (b) fluid from the contralateral cauda maintained for 13 days in the abdomen. Compared with the results after low corpus ligation (see Fig. 2), the disappearance of bands of $M_{\mathrm{r}} 18000,34-38000,52000$ and $>100000$ was consistently more clear-cut in animals with the low caudal ligation. Coomassie Blue stain.

Fig. 6. Typical 10\% SDS-PAGE gels of rat cauda fluid stained with FITC-Con A and photographed in ultraviolet light: (a) fluid from a scrotal epididymis; (b) fluid from an epididymis reflected 15 days previously to the abdomen; (c) fluid from the scrotal epididymis of a rat castrated 15 days previously. Note the minor effect of body temperature on the glycoprotein spectrum compared with the suppression seen following androgen withdrawal. 
ligation displayed no significant difference from that obtained with control samples from the nonligated epididymis. On the other hand, as can be seen in Fig. 5 there was a rather more distinctive, clear-cut loss of temperature-sensitive bands 13 days after ligation in the cauda flexure at the point shown in Fig. 1(c), compared with that after division of the distal epididymis. A rupture of the duct had occurred above the point of that ligation in 2 of the 3 rats examined at 13 days. However, there was no involvement of the open lower segment, and the results were closely similar on analysis, in all 3 animals.

Distinct changes in the protein profile of caudal fluids were seen also after castration, as others have observed (Cameo \& Blaquier, 1976; Brooks \& Higgins, 1980; Jones et al., 1980). They were qualitatively similar to, but for some bands more extreme than, the changes in fluid from the 15-day cryptepididymal cauda. After 15 days, the protein bands of $M_{\mathrm{r}} 18000,23000,48000$ and 52000 had either decreased dramatically or had disappeared, according to the individual male (Fig. 2d). Compared with normal controls run in parallel, a detectable decrease occurred also in the band complex of $M_{\mathrm{r}} 34-38000$.

When gels of control cauda fluid were stained by FITC-Con A, many bands, e.g. those co-migrating with albumin, did not bind the lectin. However, other bands were intensely fluorescent (Fig. 6). The latter include one group of $M_{\mathrm{r}}$ 34-38000, several in the range of $M_{\mathrm{r}}$ 47-60000, one of $M_{\mathrm{r}} 90000$ and others of $M_{\mathrm{r}}>120000$. Bands of $M_{\mathrm{r}} 18000$ and 23000 displayed distinct though less intense fluorescence. In fluid collected after 15 days in the abdomen, there was a moderate decrease in fluorescent protein bands of $M_{\mathrm{r}} 34-38000$, of several poorly resolved bands of $M_{\mathrm{r}} 47-60000$, as well as some of the bands of $M_{\mathrm{r}}>120000$. The decrease was more marked in the case of androgen-deficient animals assessed 15 days after castration, when FITC-ConA essentially failed to stain any bands of $M_{\mathrm{r}}<48000$, while one of $M_{\mathrm{r}} 60000$ and others around 120000 were strikingly less fluorescent (Fig. 6).

The indication from SDS-PAGE analysis that the protein composition of the luminal fluid is changed by maintenance of the cauda epididymidis at body temperature was confirmed in principle using immunoelectrophoresis. When challenged with rabbit antiserum containing antibody to the antigens in normal rat cauda fluid, three precipitation arcs clearly evoked by normal cauda fluid were either not observed, or were only faintly detectable following a similar challenge with fluid from the 15-day cryptepididymal cauda (Fig. 7).

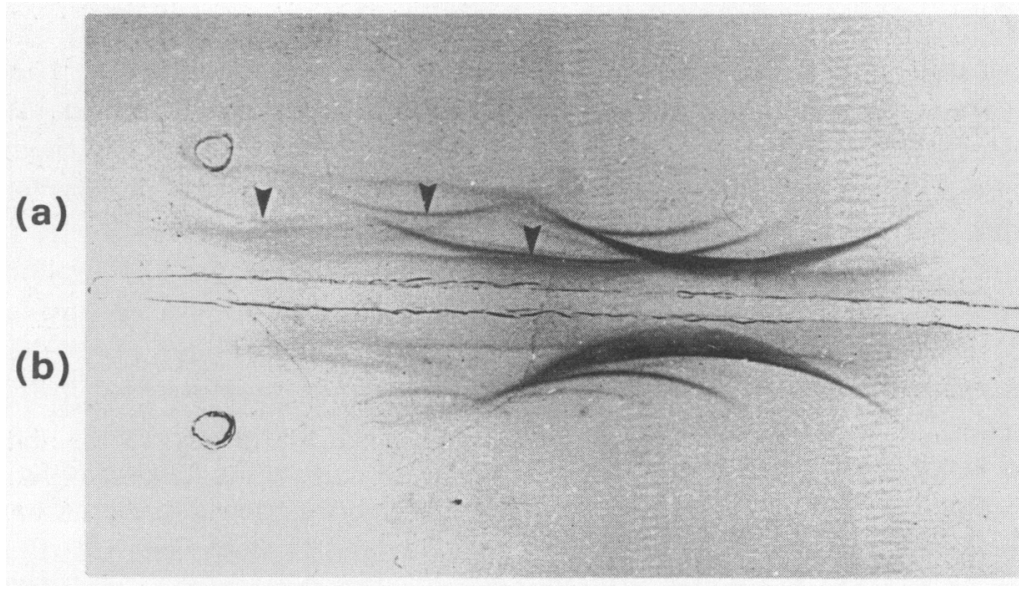

Fig. 7. Immuno-electrophoresis of (a) fluid from a scrotal cauda epididymidis; (b) fluid from a cauda epididymidis positioned for 15 days in the abdomen. The central trough contained rabbit IgG raised against normal rat cauda epididymal fluid. Arrow heads indicate three major precipitation arcs in (a) that are completely absent or are significantly reduced on side (b). Coomassie Blue stain. 


\section{Discussion}

Comparison of the daily testicular sperm production with the total number of spermatozoa in the larger tubules of the cauda epididymidis (see Amann, 1981) suggests that the mean period spermatozoa can spend in the caudal storage region is normally rather brief. That mean appears to be only about 4-5 days in the rat and perhaps 8-10 days in the rabbit. Some individual spermatozoa probably spend rather more time there, however, because of a natural mixing of spermatozoa of different absolute ages, and it is clear that the caudal environment, although not that proximal to the cauda, is potentially able to maintain some spermatozoa in a functional state for as long as 40 days in rabbits (Hammond \& Asdell, 1926), for 25 days in the guinea-pig (Young, 1929 ) and for about 20 days in rats (White, 1933). Little is known yet of the immediate factors in caudal fluid which permit prolonged sperm survival there. It is evident, however, that such survival depends acutely on testicular androgen and (in scrotal mammals) on the lower temperature in the scrotum. With regard to the effects of temperature, earlier studies (Asdell \& Salisbury, 1941; Jones \& Glover, 1973) involved elevation to the abdomen of both testis and epididymis, with a resultant loss of fertility within about 7 days in rabbits (Cummins \& Glover, 1970). In the present study, we have used a technique (Bedford, 1978) in which the epididymis alone is maintained at the temperature of the abdomen, leaving a functioning testis in the scrotum. This allows normal production of spermatozoa and their maturation to a functional state in an epididymis which, however, cannot store spermatozoa. This 'cryptepididymal' preparation therefore permits a physiological dissection of the maturation from the storage function of the epididymis.

Although there have been studies of the effects of body temperature on secretion by testicular cells (Hagenas, Ritzen, Svenson, Hansson \& Purvis, 1978; Nakamura \& Hall, 1980; Hall, Kew \& Mita, 1985), our present investigation seems to be the first to consider protein secretion by the epididymis in relation to temperature. The results indicate that some epididymis-specific proteins normally present in the caudal lumen soon disappear at body temperature. The changes in caudal proteins related to body temperature may really be more complex than reported here, and further differences might be revealed by two-dimensional electrophoresis (see Olson \& Hinton, 1985). Nevertheless, our gels establish the point in principal, and illustrate clearly that temperature and androgen withdrawal result in a disappearance from caudal fluid of many of the same molecules, the reduction in glycoprotein being more marked in the androgen-deficient duct.

While sperm maturation in the epididymis of the rat is not affected significantly by abdominal temperature (Bedford, 1978; Wong et al., 1982), this suppresses both the storage capacity (i.e. the storage volume) of the cauda and its ability to maintain a normal ionic environment (Wong et al., 1982; Rasweiler \& Bedford, 1982) and support spermatozoa in a viable state there (Bedford, 1978; Foldesy \& Bedford, 1982). This suggests some division of function with respect to its temperaturesensitivity at some yet unknown point along the epididymis. The electrophoretic patterns of material from epididymides blocked at the approach to the cauda flexure at the point shown in Fig. 1(c) seem to result in a generally more clear-cut disappearance of temperature-labile bands than in material obtained after higher blockage in the low corpus at the point designated in Fig. 1(a). A temperature-sensitive epithelial transition zone could therefore exist in the proximal cauda epididymidis.

In the cauda isolated by separation in the low corpus region or by single tubule ligation in the low cauda, initial change in the luminal fluid protein profile is detectable by 6 days at body temperature. Further changes in the protein content of caudal fluid become clearly evident by 13-15 days (Figs 2c \& 5). In Coomassie Blue-stained gels and those treated with FITC-ConA, the androgen withdrawal of castration seemed to affect a somewhat wider protein spectrum, particularly in the higher molecular weight range. In view of the nearly parallel outcome to that after castration, the temperature effects could simply reflect a suppression of protein secretion by the caudal epithelium. However, whereas obvious ultrastructural changes follow androgen 
withdrawal (Moore \& Bedford, 1979), body temperature has no significant effect on rat principal cell ultrastructure (Rasweiler \& Bedford, 1982). It therefore needs to be demonstrated that the protein changes in cauda fluid evoked at body temperature do reflect an impairment of local secretion per se, rather than selective break-down of specific macromolecules.

That some of the labile caudal proteins serve to sustain the viability of mature spermatozoa seems a possibility worth entertaining. One dimer of $M_{\mathrm{r}} 100000$ elaborated in the cauda epididymidis that binds to the acrosome has been presumed to participate in maturation (Rifkin \& Olson, 1985). However, the fact that spermatozoa can mature in the abdominal epididymis (Bedford, 1978; Wong et al., 1982) indicates that any function of temperature-sensitive caudal proteins probably involves storage. In that regard it is of interest that some change was detectable here after only 6 days at body temperature, when effects of androgen withdrawal on protein secretion also are observed (Kohane, Cameo, Pineiro, Garbieri \& Blaquier, 1980; Jones et al., 1980 ), since that interval coincides with the time at which spermatozoa retained in the rat cauda die after imposition of either state. However, body temperature and androgen withdrawal both also suppress the ability of caudal principal cells to imbibe water and $\mathrm{Na}^{+}$(Wong \& Yeung, 1978; Wong et al., 1982; Rasweiler \& Bedford, 1982), changing the fluid's ionic composition. This poses a question as to the relative importance of the specific ionic and protein content of the fluid in the cauda for the ability to store spermatozoa.

P.E. is the recipient of a Norman and Rosita Winston Fellowship. The study was supported in part by NIH grant HD 15528.

\section{References}

Amann, R.P. (1981) A critical review of methods for evaluation of spermatogenesis from seminal characteristics. J. Androl. 2, 37-58.

Asdell, S.A. \& Salisbury, G.W. (1941) The viability of spermatozoa in the abdominal epididymis and the failure of motile sperms to fertilize ova. Am. J. Physiol. 132, 791-795.

Bedford, J.M. (1978) Influence of abdominal temperature on epididymal function in the rat and rabbit. Am. J. Anat. 152, 509-522.

Brooks, D.E. (1983) Effect of androgens on protein synthesis and secretion in various regions of the rat epididymis as analysed by two-dimensional gel electrophoresis. Molec. cell. Endocr. 29, 255-270.

Brooks, D.E. \& Higgins, S.J. (1980) Characterization and androgen dependence of proteins associated with luminal fluid and spermatozoa in the rat epididymis. J. Reprod. Fert. 59, 363-375.

Cameo, M.S. \& Blaquier, J.A. (1976) Androgencontrolled specific proteins in rat epididymis. $J$. Endocr. 69, 47-55.

Cummins, J.M. \& Glover, T.D. (1970) Artificial cryptorchidism and fertility in the rabbit. J. Reprod. Fert. 23, 423-433.

Dyson, A.L.M. \& Orgebin-Crist, M-C. (1973) Effect of hypophysectomy, castration and androgen replacement upon the fertilizing ability of rat epididymal spermatozoa. Endocrinology 93, 391-402.

Foldesy, R.G. \& Bedford, J.M. (1982) Biology of the scrotum. I: Temperature and androgen as determinants of the sperm storage capacity of the rat cauda epididymidis. Biol. Reprod. 26, 673-682.
Glover, T.D. (1960) Spermatozoa from the isolated cauda epididymis of rabbits and some effects of artificial cryptorchidism. J. Reprod. Fert. 1, 121-129.

Hagenas, L., Ritzen, E.M., Svenson, J., Hansson, V. \& Purvis, K. (1978) Temperature dependence of Sertoli cell function. Int. J. Androl., Suppl. 2, 449462.

Hall, P.F., Kew, D. \& Mita, M. (1985) The influence of temperature on the functions of cultured Sertoli cells. Endocrinology 116, 1926-1932.

Hammond, J. \& Asdell, S.A. (1926) The vitality of the spermatozoa in the male and female tracts. Br.J. exp. Biol. 4, 155-169.

Heller, R.E. (1929) New evidence for the function of the scrotum. Physiol. Zool. 2, 9-17.

Jones, R. \& Glover, T.D. (1973) The effects of castration on the composition of rabbit epididymal plasma. $J$. Reprod. Fert. 34, 405-414.

Jones, R., Brown, C.R., Von Glos, K.I. \& Parker, M.G. (1980) Hormonal regulation of protein synthesis in the rat epididymis. Biochem. J. 188, 667-676.

Kohane, A.C., Cameo, M.S., Pineiro, I., Garbieri, J.C. \& Blaquier, J.A. (1980) Distribution and site of production of specific proteins in the rat epididymis. Biol. Reprod. 23, 181-187.

Laemmli, U.K. (1970) Cleavage of structural proteins during the assembly of the head of bacteriophage T4. Nature, Lond. 227, 680-685.

Lea, O.A., Petrusz, P. \& French, F.S. (1978) Purification and localization of acidic epididymal glycoprotein (AEG): a sperm coating protein secreted by the rat epididymis. Int. J. Androl., Suppl. 2, 592-607.

Lowry, O.H., Rosebrough, N.J., Farr, A.L. \& Randall, 
R.J. (1951) Protein measurement with the Folin phenol reagent. J. biol. Chem. 193, 265-275.

Moore, C.R. (1928) On the properties of the gonads as controllers of somatic and physical characteristics. X: Spermatozoon activity and the testis hormone. $J$. exp. Zool. 50, 455-494.

Moore, H.D.M. \& Bedford, J.M. (1979) The differential absorptive activity of epithelial cells of the rat epididymis before and after castration. Anat. Rec. 199, 313-327.

Nakamura, M. \& Hall, P.F. (1980) The mechanism by which body temperature inhibits protein biosynthesis in spermatids of rat testis. J. biol. Chem. 255, 2907-2913.

Olson, G.E. \& Hinton, B.T. (1985) Regional differences in luminal fluid polypeptides of the rat testis and epididymis revealed by two dimensional gel electrophoresis. J. Androl. 6, 20-34.

Orgebin-Crist, M-C. \& Jahad, N. (1978) Maturation of rabbit epididymal spermatozoa in organ cultureinhibition by anti-androgens and inhibitors of ribonucleic acid and protein synthesis. Endocrinology 103, 46-53.

Orgebin-Crist, M-C., Danzo, B.J. \& Davis, J. (1975) Endocrine control of the development and maintenance of the sperm fertilizing ability in the epididymis. In Handbook of Physiology. Section 7, Vol. V, pp. 319-383. Eds D. W. Hamilton \& R. O. Greep. American Physiological Society, Washington, D.C.
Rasweiler, J.J. \& Bedford, J.M. (1982) Biology of the scrotum. III. Effect of abdominal temperature upon the epithelial cells of the rat cauda epididymidis. Biol. Reprod. 26, 691-705.

Rifkin, J.M. \& Olson, G.E. (1985) Characterization of maturation dependent extrinsic proteins of the rat sperm surface. J. Cell Biol. 100, 1582-1591.

Turner, T.T., Plesums, J.L. \& Cabot, C.L. (1979) Luminal fluid proteins of the male rat reproductive tract. Biol. Reprod. 21, 883-890.

Wong, P.Y.D. \& Yeung, C.H. (1978) Absorptive and secretory functions of the perfused rat cauda epididymidis. J. Physiol., Lond. 275, 13-26.

Wong, P.Y.D., Au, C.L. \& Bedford, J.M. (1982) Biology of the scrotum. II. Suppression by abdominal temperature of transepithelial ion and water transport in the cauda epididymidis. Biol. Reprod. 26, 683-689.

White, W.E. (1933) The duration of fertility and the histological changes in the reproductive organs after ligation of the vasa efferentia in the rat. Proc. $R$. Soc. $B 113,544-552$.

Wray, W., Boulikas, T., Wray, W.P. \& Hancock, R. (1981) Silver staining of proteins in polyacrylamide gels. Analyt. Biochem. 118, 197-203.

Young, W.C. (1929) A study of the function of the epididymis. II: The importance of an aging process in sperm for the length of the period during which fertilizing capacity is retained by sperm isolated in the epididymis of the guinea pig. $J$. Morph. 48, 475-489.

Received 24 February 1986 